\title{
Jalan Terjal UMKM dan Pedagang Kecil Bertahan \\ di Tengah Pandemi Covid-19 dan Ancaman Krisis Ekonomi Global
}

\author{
Beni Dwi Komara (1) \\ Heri Cahyo Bagus Setiawan (2) \\ Aries Kurniawan (3) \\ Universitas Muhammadiyah Gresik (1)(2)(3) \\ benikomara@umg.ac.id ${ }^{(1)}$ \\ hericbs@umg.ac.id ${ }^{(2)}$ \\ ariesaja@umg.ac.id ${ }^{(3)}$
}

\begin{abstract}
Wednesday, April 1, 2020, Minister of Finance Sri Mulyani Indrawati said that the four sectors most affected by the corona Covid-19 epidemic were households, MSMEs, corporations, and the financial sector. Households will experience a significant decline in terms of consumption because the community is no longer active outside the home so that purchasing power is decreasing and threatened with loss of income because they cannot work to fulfill their basic needs especially for poor and vulnerable families in the informal sector. The micro small and medium business sector (MSME) is under pressure due to not being able to conduct business activities so that the ability to meet credit obligations is disrupted, this increases the bank's Non-Performing Loans (NPL) for MSMEs further worsening economic conditions. At the time of the 1997-1998 crisis where SMEs as economic saviors, now suffered a huge blow because there are restrictions on economic and social activities. (Tempo, 2020). This research is to find out the economic impact in the co-19 pandemic vortex that is happening in the community, especially for MSMEs \& small traders and to know how they can take to survive the global crisis that is in front of their eyes? Will they return to being heroes like during the 1997-1998 crisis or will it fall this time.
\end{abstract}

Keywords: covid-19 pandemic; global economic crisis; policy; SMEs; small traders 
Rabu, 1 April 2020, Menteri Keuangan Sri Mulyani Indrawati menyampaikan bahwa empat sektor yang paling tertekan akibat wabah virus corona Covid-19 yaitu rumah tangga, UMKM, korporasi, dan sektor keuangan. Rumah tangga akan mengalami penurunan cukup besar dari sisi konsumsi karena masyarakat sudah tidak beraktivitas di luar rumah sehingga daya beli pun menurun dan terancam kehilangan pendapatan karena tidak dapat bekerja untuk memenuhi kebutuhan dasarnya terutama bagi keluarga miskin dan rentan di sektor informal. Sektor usaha mikro kecil dan menengah (UMKM) mengalami tekanan akibat tidak dapat melakukan kegiatan usaha sehingga kemampuan untuk memenuhi kewajiban kredit terganggu, hal ini menaikkan Non Performing Loan (NPL) perbankan untuk UMKM semakin memperburuk kondisi perekonomian. Saat krisis 1997-1998 dimana UMKM sebagai penyelamat ekonomi, saat ini mengalami pukulan yang sangat besar karena ada pembatasan kegiatan ekonomi dan sosial. (Tempo, 2020). Penelitian ini untuk mengetahui dampak ekonomi di pusaran pandemi covid-19 yang terjadi di masyarakat terutama bagi umkm \& pedagang kecil dan mengetahui bagaimana langkah yang bisa mereka lakukan untuk bisa bertahan menghadapi krisis global yang sudah didepan mata? Apakah mereka akan kembali menjadi pahlawan seperti saat krisis 1997-1998 atau bakalan tumbang kali ini.

\section{Kata Kunci : pandemi covid-19; krisis ekonomi global; kebijakan; UMKM; pedagang kecil}




\section{PENDAHULUAN}

WHO telah menetapkan COVID-19 sebagai pandemi. Hal ini berarti Covid-19 memiliki peningkatan jumlah kasus penyakit secara tiba-tiba pada suatu populasi di daerah tertentu telah menyebar ke beberapa negara atau benua, dan umumnya menjangkiti banyak orang. Meskipun tingkat kematian yang disebabkannya masih kalah dengan virus flu burung, atau demam berdarah. Namun, Covid-19 bisa sangat berbahaya bagi penduduk berusia lanjut atau mereka yang memiliki riwayat penyakit jantung, diabetes, darah tinggi dan penyakit pernapasan akut. Peningkatan Penularan bisa terjadi secara exponensial di suatu daerah hingga virus ini kini menjadi pandemi Covid-19 yang sudah mempengaruhi seluruh dunia karena telah menyebar ke lebih dari 211 negara. Pengambil kebijakan di setiap negara akan mengambil langkah cepat untuk mengurangi makin banyaknya warga yag tertular wabah ini diantaranya dengan cara memutus matarantai penularan melalui penerapan social distancing yang bertujaun agar mencegah orang yang sakit untuk kontak dalam jarak 2 meter dengan mereka yang sehat agar tidak terjadi penularan. Kebijakan ini mengharuskan orang-orang untuk melakukan semua aktivitasnya dari rumah, seperti bekerja, belajar, beribadah dan berkegiatan sosial. agar bisa bekerja rumah. Sehingga pabrik, sekolah, perguruan tinggi tempat ibadah, pasar keuangan, kantor perusahaan, bisnis dan acara-acara yang menimbukan keramaian ditutup. Lebih jauh lagi tingkat eksponensial di mana virus itu menyebar, dan meningkatnya ketidakpastian tentang seberapa buruk situasi itu bisa, mengarah pada keselamatan dalam konsumsi dan investasi di antara konsumen, investor dan mitra dagang internasional. Selanjutnya sosial distancing dan ketidakpastian situasi ini selanjutnya mengarah kepada krisis ekonomi global. (Ozili, 2020).

Para pengambil kebijakan sangat sadar dengan siatuasi ini dan dengan cepat melakukan tindakan lain selain bebagai macam pembatasan gerak, juga meakukan tindakan kebijakan moneter, tindakan kebijakan fiskal, dan tindakan kesehatan masyarakat untuk menangani Covid-19 dan mengurangi dampak sosial ekonomi.

Di Indonesia pun demikian, Presiden secara resmi mengumumkan kasus pertama positif Covid-19 di Indonesia pada 2 Maret 2020. Sejak itu laporan penderita terus bertambah dengan cepat,hingga hari ke-40 grafik penambahan pasien positif masih terus menanjak tinggi dan belum ada tanda-tanda mengalami penurunan. Bahkan Pusat Pemodelan Matematika dan Simulasi (P2MS) Institut Teknologi Bandung (ITB) memprediksi epidemi virus corona (SARSCOV-2) akan berakhir di Indonesia pada akhir Mei hingga awal Juni 2020.( Putri, Kompas.com, 2020). Hal ini berarti ekonomi Indonesia juga berada diambang krisis. Dulu saat krisi 97-98 umkm dan pedagang kecil adalah pahlawan penyelamat perekonomian. Tapi sekarang berbeda 
situasinya. Apakah mereka akan tetap menjadi pahlawan atau bahkan pecundang kali ini. Penelitian ini untuk mengetahui dampak ekonomi di pusaran pandemi covid-19 yang terjadi di masyarakat terutama bagi UMKM \& pedagang kecil dan mengetahui bagaimana langkah yang bsia mereka lakukan untuk bisa bertahan menghadapi krisis global yang sudah di depan mata?

\section{METODE PENELITIAN}

Metode kualitatif dengan paradigma interpretatif menantang gagasan bahwa realitas sosial adalah sesuatu yang kita terima begitu saja. Sesuatu "dari luar sana" yang membentuk tindakan masyarakat. Peneliti interpretatif meyakini teori kontruktivisme sosial (Social Constructivism) yang mengemukakan gagasan bahwa "realitas" yang kita tinggali ini terbentuk dari waktukewaktu melalui proses komunikasi, interaksi kita dengan orang-orang di sekitar kita, dan sejarah kita bersama. Realitas, oleh karena itu merupakan "hal-hal yang dimiliki bersama dan diterima sebagaimana cara dunia dipersepsi dan dipahami” (Locke, 2001:9 dalam Daymon, C., \& Holloway, I. 2007). Teknik pengumpulan data yang digunakan yaitu studi literartur dan wawancara langsung ke lapangan dengan pendekatan indepth interview (dengan 4 informan dari pelaku UMKM dan pedagang kecil). Proses Teknik Analisisnya dengan merekam, mentranskip keseluruhan hasil wawancara kemudian untuk dikategorisasikan sesuai dengan kebutuhan untuk menjawab pertanyaan dan tujuan dari penelitian yang akan kami lakukan. Tujuannya, supaya kami dengan mudah mengambil kesimpulan dari setiap informasi. Kemudian, kami membahas dan menganalisa setiap kutipan yang berhubungan dengan konten bahasan penelitian yaitu untuk mengetahui dampak ekonomi di pusaran pandemi covid-19 yang terjadi di masyarakat terutama bagi UMKM \& pedagang kecil dengan bantuan lampiran hasil transkip. Untuk Trianggulasinya penelitian kami menggunakan Trianggulasi Sumber.

\section{HASIL DAN PEMBAHASAN \\ Pandemi Covid-19 Menyeret Dunia dalam Krisis Ekonomi Global}

Dampak COVID-19 yang sudah tampak diantranya pasar saham global menghapus kekayaan sekitar US \$ 6 triliun dalam satu minggu dari 24 - 28 Februari, pada kurun waktu yang sama Indeks S\&P 500 di Amerika kehilangan nilai lebih dari \$ 5 triliun, sementara 10 perusahaan terbesar S\&P 500 mengalami kerugian gabungan lebih dari \$ 1,4 triliun. Kerugian disebabkan oleh penilaian rasional oleh investor bahwa laba perusahaan akan menurun karena dampak coronavirus. Asosiasi Transportasi Udara Internasional (IATA) menyatakan bahwa industri perjalanan udara akan kehilangan US \$ 113 miliar jika wabah COVID-19 tidak dengan cepat tertahan. IMF menurunkan proyeksi pertumbuhannya untuk ekonomi global. Industri 
pariwisata terpengaruh karena pembatalan penerbangan, pemesanan hotel dibatalkan dan acara lokal dan internasional dibatalkan bernilai lebih dari \$ 200 miliar. Aliran barang melalui rantai pasokan Global sangat berkurang karena Cina adalah produsen dan eksportir terbesar dunia, dan pemerintah Cina memerintahkan penutupan pabrik-pabrik besar. Negara-negara seperti Iran, Italia, dan Prancis mengeluarkan kebijakan nasional tetap tinggal di rumah untuk mengendalikan penyebaran virus, yang telah menyebabkan banyak kematian dan memberikan tekanan pada infrastruktur kesehatan publik nasional. Ini memicu resesi global di negaranegara maju. Ada konsensus umum di antara para ekonom bahwa pandemi coronavirus menjerumuskan dunia ke dalam resesi global (Financial Times, 2020 diambil dari Ozili, 2020)

Lebih jauh lagi kondisi yang mengarah pada resesi global ini menunjukkan tantangan lebih banyak dibandingkan dengan krisis sebelumnya. Berikut beberapa tantagan tersebut, Ini adalah pandemi global, tidak fokus pada negara-negara berpenghasilan menengah ke bawah, Suku bunga berada pada posisi terendah dalam sejarah, Dunia saat ini jauh lebih terintegrasi, Krisis saat ini menghasilkan efek limpahan di seluruh rantai pasokan, Telah terjadi menghancurkan permintaan dan penawaran secara bersamaan. (Fernandes, N.,2020).

Berikut daftar sosial, ekonomi dan Bisnis diluar negeri yang memiliki hubungan dengan UMKM yang terdampak pandemi Covid-19, diantranya adalah : Pembatalan pertemuan publik dan acara olahraga, Operator pelayaran membatalkan pelayaran sampai Mei, Maskapai telah menerbangkan armada Airbus A380 mereka, Maskapai meminta karyawan untuk mengambil cuti dua bulan yang tidak dibayar, NBA, liga sepak bola, Formula 1 ditangguhkan hingga pemberitahuan lebih lanjut, Maersk membatalkan 50 pelayaran karena coronavirus, 5 juta orang telah kehilangan pekerjaan di Tiongkok, Cineplex Inc. Kanada menutup semua dari 165 bioskopnya, McDonald's menutup area tempat duduk di A.S., Lufthansa mengurangi 90\% dari penerbangan jarak jauh dan membatalkan lebih dari 23000 penerbangan hingga akhir April, Jaringan TV olahraga menghadapi penurunan mendadak dalam pendapatan iklan, Amazon dan Facebook telah mengeluarkan estimasi pendapatan iklan yang lebih rendah, Jerman telah menawarkan kepada perusahaan pinjaman "tidak terbatas" untuk menghentikan mereka dari keruntuhan, Airbus menghentikan sementara produksi di Perancis dan Spanyol, Untuk bulan Maret dan April 2020, operator hotel Swiss mengharapkan omset turun 45\%, Gucci dan Hermes, perusahaan barang mewah, menutup semua lokasi produksi mereka, Galangan kapal Italia Fincantieri telah meminta para pekerjanya untuk menggunakan waktu liburan tahunan mereka, 145 pengemudi telah diberhentikan di Port of Los Angeles, karena kapal-kapal dari China berhenti tiba, Ryanair memperkirakan penurunan 80\% dalam penerbangan untuk bulan April dan Mei, Raksasa pariwisata Jerman, TUI, telah 
meminta bantuan negara, Swiss hanya terbuka untuk warga negara, penduduk, dan penumpang, Perdagangan di NYSE terhenti beberapa kali selama sepekan terakhir, karena pemutus sirkuit terus terputus, Kejuaraan Sepak Bola Eropa telah dibatalkan dan masih banyak lagi lainya. (Fernandes, N.,2020).

\section{Langkah Cepat Pengambil Kebijakan}

Langkah-langkah kebijakan yang diperkenalkan oleh para pembuat kebijakan di seluruh dunia untuk mengatasi resesi global yang disebabkan oleh virus korona dapat dibagi menjadi empat kategori: (i) tindakan moneter, (ii) tindakan fiskal, (iii) tindakan kesehatan masyarakat, dan (iv) manusia langkah-langkah kontrol

Tabel 1

Langkah Kebijakan

\begin{tabular}{|l|c|c|c|c|}
\hline \multicolumn{1}{|c|}{ Negara } & $\begin{array}{c}\text { Total Peningkatan } \\
\text { Pengeluaran } \\
\text { Langsung }\end{array}$ & $\begin{array}{c}\text { Prosentase } \\
\text { dibanding } \\
\text { GDP }\end{array}$ & $\begin{array}{c}\text { Dukungan Fiskal } \\
\text { Melalui Pinjaman dan } \\
\text { Jaminan Pinjaman }\end{array}$ & $\begin{array}{c}\text { Prosentase } \\
\text { dibanding GDP }\end{array}$ \\
\hline Amerika & USD 2 Triliun & 9,3 & USD 700 Miliar & 3,3 \\
\hline Inggris & GBP 330 Miliar & 11,80 & GBP 300 Miliar & 10,7 \\
\hline Chechnya & CZK 100 Miliar & 1,80 & CZK 900 Miliar & 15,9 \\
\hline Polandia & PLN 70 Miliar & 3,10 & PLN 140 Miliar & 6,2 \\
\hline Arab Saudi & - & - & SAR 70 Miliar & 2,4 \\
\hline Turki & - & - & TRY 100 Miliar & 2,3 \\
\hline
\end{tabular}

Sumber (Ozili, P. K., \& Arun, T. 2020)

Sejumlah negara mengalokasikan besaran anggaran kesehatan lebih dari 2 persen dari produk domestik bruto atau PDB untuk mencegah penyebaran virus korona. Sedangkan anggaran Indonesia untuk penanganan pandemik Covid-19 masih relatif kecil, yaitu kurang dari 1 persen PDB. Oleh karena itu, tidak cukup jika Indonesia hanya bergantung pada Anggaran Pendapatan dan Belanja Negara (APBN). Sri Mulyani mengatakan, anggaran yang ada untuk penanganan temporer selama 3-6 bulan. Dengan dana itu, pemerintah akan memastikan ketersediaan alat pelindung diri, memberikan insentif bagi tenaga medis berkisar Rp 5 juta-Rp 15 juta per bulan tergantung profesinya, dan mengganti biaya perawatan pasien Covid-19. Seluruh instrumen fiskal di pusat maupun daerah fokusnya adalah untuk kesehatan. Selanjutnya untuk peningkatan jaring pengaman sosial dan bantuan bagi dunia usaha. (Kompas,2020). Hal ini sebagaimana telah diupayakan oleh Pemerintah bahwa upaya-upaya telah dilakukan yaitu pemerintah menambah jumlah stimulus dari saat ini totalnya sebesar Rp. 405 triliun menjadi Rp. 1.600 triliun (tempo.co, diakses 26/4/2020) 


\section{Profil UMKM \& Pedagang Kecil Indonesia}

Pengertian Pedagang Kecil adalah Pengecer atau toko pengecer adalah sebuah lembaga yang melakukan kegiatan usaha menjual barang kepada konsumen akhir untuk keperluan pribadi (Basu Swasta, 1984:192 dalam Haristiana, 2005; Kusuma dan Darma, 2020) ). Beberapa penggolongan pedagang kecil antara lain : Pedagang daging dan ikan, Pedagang tekstil dan pakaian, Pedagang sayur dan rempah-rempah, Pedagang kelontong, Pedagang makanan dan minuman, Pedagang buah-buahan, Penjual jasa, Pedagang loak dan sebagainya, Pengertian pedagang kecil yang peneliti maksud adalah pengecer atau toko pengecer, usaha kecil dan atau yang dapat dipersamakan dengan itu. (Haristiana, 2005; Kusnadi dan Darma, 2018). Sedangkan UMKM pengertianya berdasarkan Undang-Undang No.20 Pasal 1 Tahun 2008 tentang Usaha Mikro,Kecil dan Menengah dengan kriteria sesuai diatur dalam Pasal 6 UU No.20 Tahun 2008 tentang kreteria UMKM dalam bentuk permodalan. Sektor UMKM memiliki kemampuan yang handal dan mumpuni serta berperan penting dalam kancah perekonomian Nasional. UMKM memiliki proporsi sebesar 99,99\% dari total keseluruhan pelaku usaha di Indonesia atau sebanyak 56,54 juta unit. Usaha Mikro, Kecil, dan Menengah telah mampu membuktikan eksistensinya dalam perekonomian di Indonesia. Ketika badai krisis moneter melanda Indonesia di tahun 1998 usaha berskala kecil dan menengah yang relatif mampu bertahan dibandingkan perusahaan besar. Karena mayoritas usaha berskala kecil tidak terlalu tergantung pada modal besar atau pinjaman dari luar dalam mata uang asing. Sehingga, ketika ada fluktuasi nilai tukar, perusahaan berskala besar yang secara umum selalu berurusan dengan mata uang asing adalah yang paling berpotensi mengalami imbas krisis. Namun UMKM Indonesia memiliki kelemahan yaitu kurangnya permodalan baik jumlah maupun sumbernya dimana pertumbuhan kredit yang dikucurkan sektor perbankan hanya 13,6\%, kurangnya kemampuan manajerial dan keterampilan beroperasi dalam mengorganisir dan terbatasnya pemasaran. Disamping hal-hal terdapat juga persaingan yang kurang sehat dan desakan ekonomi sehingga mengakibatkan ruang lingkup usaha menjadi sempit dan terbatas. Namun semua permasalah itu bisa terselesaikan dengan beberapa kebijakan yang membuka peluang bagi UMKM untuk dapat mengakses industri perbankan dengan mudah. (Suci, Y. R. 2017).

Pak Udin pedagang sepeda motor bekas menyampaikan, “ .. Ditempat kita sebenarnya kalau mau usaha banyak sekali peluang mau jual ini itu bisa, pembeli banyak. Rata-rata pedagang disini kepentok sama modal... pinjam ke bank resmi banyak sarat, belum lagi jaminan gak punya. Kalau orang gak telaten ngumpulin modal sendiri ujung-ujungnya 
rentenir. Selanjutnya Bu Lastri penjual peralatan rumahtangga juga mengungkapkan, “Jualan begini dulu cukup rame, sekarang tidak seberapa kalah sama mart-mart itu modalnya lebih gede... orang beli pindah kesitu lebih adem tempatnya, kalau pasar sumpek."

Pedagang kecil atau pedagang tradisional merupakan pelaku ekonomi kerakyatan yang berjuang hidup dengan mandiri tanpa bantuan siapapun untukmenghidupi keluarga. Pedagang Tradisional berada dalam sistem ekonomi, maka negara tidak mudah melakukan kesewenangwenangan, seperti membiarkan persaingan, kompetisi tidak sehat antara pedagang tradisonal dengan pedagang ritel modern seperti Indo Mart dan Alfa Mart.Kehadiran pasar modern atau pasar swalayan, ritel membuat "goncang Ekonomi" bagi pedagang tradisonal sehingga berakibat pedagang tradisional hidup enggan, mati tak mau. Bila kondisi ini dibiarkantidak terkendali, maka tidak menutup kemungkinan akan menciptakan kerawanan sosial, yakni pedagang menjadi pengangguran, pengemis, yang akan memicu kriminalitas. (Komara \& Prasetya, 2019).

Struktur ekonomi dan bisnis sejak jaman kolonial Belanda, era kemerdekaan, orde lama, orde baru bahkan di era reformasi yang masih saja sama sejak dulu membuat pengusaha level kecil dan menengah sama sekali tidak bisa berkembang dan terbiasa dengan slowdown ekonomi . Struktur ekonomi bisnis di indonesia pada sektor bisnis internasional mayoritas dikuasai multi nasinal company (dulu VOC/Belanda) dan minoritas the crazy RICH (elit ekonomi) yang dibina sejak awal oleh pemerintah dengan dalih stabilitas politik terhadap dominasi kekuatan politik sayap kanan, sektor bisnis lokal yg bersifat produk massal oleh kalangan elit ekonomi dan ekonomi kecil yang di upayakan dengan terseok-seok oleh umkm karena keterbatasan kepemilikan dan akses sumber daya alam, sumberdaya manusia dan modal yang ada. (Vedi Hadiz, 2017)

\section{Dampak Pandemi Covid-19 Terhadap UMKM \& Pedagang Kecil}

Pandemi Covid-19 menyebabkan hilangnya pembeli, karena mereka harus tinggal dirumah dan rumah tangga juga memperketat pengeluaran terkait menurunnya pendapatan. UMKM dan pedagang kecil ada yang masih bisa beroperasi dan ada yang memilih tutup dalam waktu yang belum bisa ditentukan. Hal ini seperti diungkapkan, “ ...Turun penjualan biasanya bisa jualan sampai 500ribu perhari sekarang maksimal 350ribu bisa kurang dari itu bahkan. Harus tetap jualan karena penghasilan hanya dari sini saja..” Hal serupa diungkapkan Heru pedagang bubur kacang hijau Pak Samin penjual bakso, “ Saya masih bisa jualan Alhamdulillah, pembeli saya orang rumahtangga sekitar sini.. turun penjualan biasanya 
sampai 700ribu perhari sekarang 350ribu sampai 500ribu. Syukur masih bisa jualan, itu tukang bubur pisang ijo dia pulang desa tidak jualan lagi rugi soalnya pembelinya kebanyakan orang kantoran yang sekarang libur.

Pemilik usaha kecil yang mencoba mengatasi pandemi coronavirus akan menghadapi pukulan finansial yang kemungkinan akan lebih buruk daripada apa yang mereka alami selama Resesi Hebat lebih dari satu dekade lalu, banyak bisnis kecil tidak akan bertahan lebih dari sebulan. Usaha kecil telah diperkecil dan ditutup sementara karena konsumen tinggal di rumah untuk membendung penyebaran virus yang sangat menular, yang juga dikenal sebagai COVID-19. Tanpa uang tunai masuk, banyak bisnis kecil - terutama restoran dan toko di American Main Streets - akan segera perlu memotong staf atau tutup untuk selamanya. Bagi banyak bisnis kecil ini, arus kas harian adalah sumber kehidupan mereka. (Karen G. Mills dari Kost, 2020).

Sementara itu mengutip JPMorgan Chase Institute memperkirakan bahwa rata-rata bisnis kecil memiliki cadangan tunai 27 hari, tetapi bisnis Main Street seringkali memiliki nilai kurang dari 20 hari. Sesuai ilustrasi berikut:

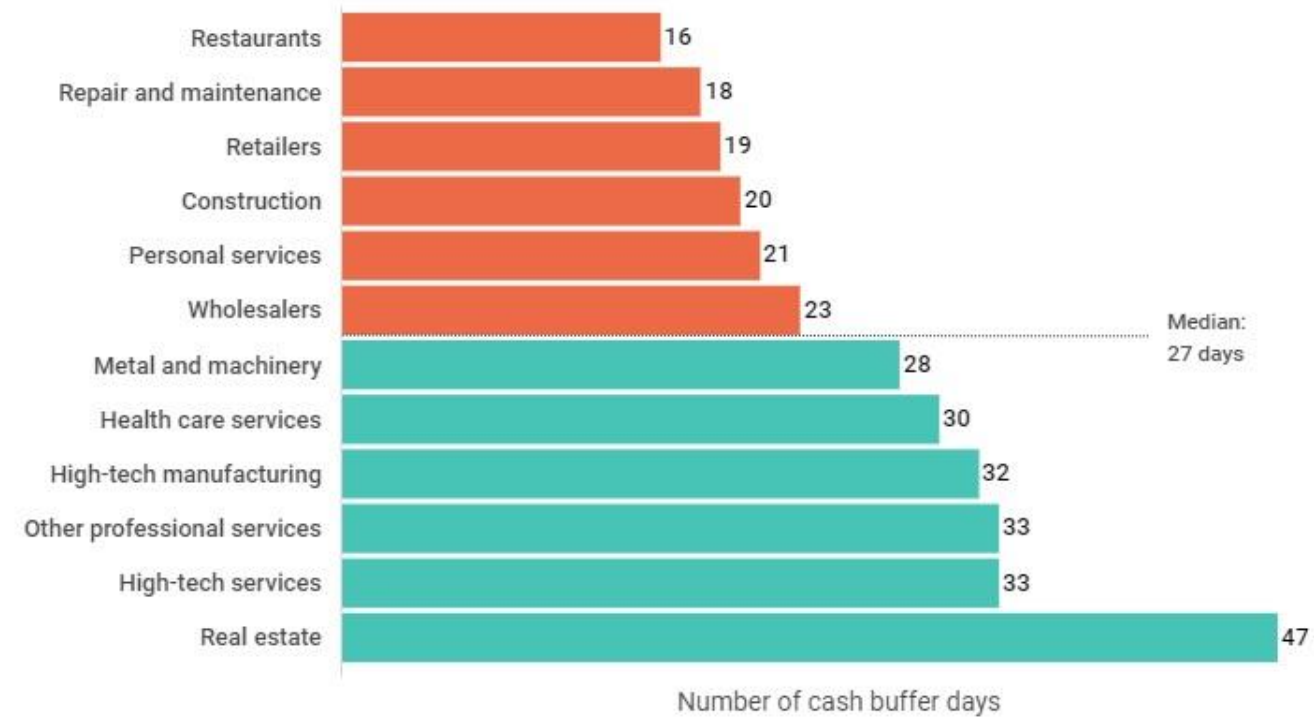

Source: The JPMorgan Chase Institute's "Cash is King: Flows, Balances, and Buffer Days;' September 2016

Jumlah hari Cadangan Tunai Sumber : The JPMorgan Chase Institute's

Sementara perkiraan bervariasi, banyak ahli kesehatan masyarakat tidak berharap wabah koronavirus mereda setidaknya selama delapan minggu, dengan asumsi bahwa jarak sosial dan upaya mitigasi lainnya dapat memperlambat penyebaran. Realitas suram semakin meresap. Sekitar 77 persen pemilik usaha kecil mengatakan mereka "sangat khawatir" tentang 
dampak ekonomi COVID-19, menurut survei Asosiasi Usaha Kecil Nasional di Amerika. Hampir setengah dari 950 orang yang disurvei mengatakan bahwa permintaan pelanggan turun, dan sepertiga responden mengalami gangguan rantai pasokan. Lebih dari setengahnya memperkirakan AS akan mengalami resesi selama 12 bulan ke depan, naik dari 14 persen pada Januari. (Kost,2020). Sementara itu Ketua Kebijakan Publik Asosiasi Pengusaha Indonesia (Apindo) Sutrisno Iwantono, mengatakan daya tahan pengusaha di Indonesia memang berbeda tergantung sektornya. Namun, secara umum mereka hanya akan kuat dalam artian sanggup membiayai pengeluaran tanpa pemasukan, sampai akhirnya tutup. Ini hanya kuat sampai tiga bulan ke depan apabila corona belum berakhir.(CNBN, 2020)

\section{Langkah Bertahan Menghadapi Krisis Ekonomi Global}

\section{Dengan Kesadaran Penuh Menerima Situasi Dan Tetap Bersyukur}

Pandemi Covid-19 ini telah meningkatnya ketidakpastian, kekhawatiran, dan ketakutan sehingga tekanan hidup serasa semakin berat. Kepasarahan kepada Allah SWT sebagai satu-satunya Tuhan yang menciptakan, mengatur, menghidupkan, mematikan, memberikan rezeki kepada makhluk-makhluk yang ada di langit dan di bumi, Sehingga mengantarkan kepada motivasi diri yang kuat, bahwa segala sesuatu dikerjakan hanya untuk mencari ridho Allah semata. Ridho Allah nikmatnya melebihi apapun yang ada di bumi dan di langit. Pemahaman ini mengantarkan pada kekuatan untuk menghadapi segala permasalahan dan cobaan hidup yang menerpa, serta menjadi bahan rujukan ketika membuat solusi atas permasalahan-permasalahan yang menimpanya. (BD Komara, Indro Kirono, Asep Saepuloh,2019). Hal ini senada dengan penyampaian Pak Purwanto (54) pemilik usaha pemborong yang orderan makin sulit, “ Sebenarnya kasihan banyak kuli dan tukang gak bisa kerja padahal mereka sudah menggantungkan pada usaha ini... tidak apa-apa disyukuri saja supaya lebih tenang, Insyallah Allah maha tahu yang terbaik untuk kita.. saya usahakan terus bahagia supaya tidak stress..” (BD Komara, Indro Kirono, Asep Saepuloh, 2019).

Tetap bersyukur hingga saat ini diri, keluarga dan lingkungan secara mayoritas masih diberikan kesehatan oleh Allah SWT sehingga masih memiliki harapan untuk berkarya di hari esok. Keikhlasan dan sikap bersyukur diharapkan akan mampu memberi kekuatan moral dan memperkuat imunitas tubuh yg sangat dibutuhkan melawan pandemi virus covid-19 in. Kesadaran kita sebagai manusia sebenarnya sama dengan cara kita melihat dan memandang realitas. Karenanya persepsi, keyakinan, pola pikir, dan nilai-nilai yang Anda pegang saat ini merupakan buah dari kesadaran yang kita jalani. Sering orang bilang, jika kita sudah bisa 
mengambil hikmah dari apa yang telah terjadi maka kita disebut "naik kelas/level". Hal ini sebenarnya dinamakan sebagai pergeseran kesadaran. Karena sebuah pencerahan baru, kita bisa melepaskan diri dari kesadaran lama. Sehingga hasilnya kita memperoleh pelajaran baru dan bisa bersikap lebih dewasa. Dalam risetnya Dr Hawkins memformulasikan sebuah hirarki model dari pengembangan diri. Model ini memiliki skala dari 0-1000 yang menggambarkan tingkat kesadaran manusia. Dimana 0 sebagai tingkat terendah dan 1000 sebagai tingkat tertinggi dari kesadaran. (Hawkins, 2013). Lebih jauh lagi penelitian yang dilakukan Julianto (2015) menunjukkan bahwa membaca Al Fatihah reflektif intuitif dapat mengubah persepsi subjek terhadap permasalahan dalam hidupnya. Subjek mulai melihat apa yang sedang terjadi pada diri mereka dengan menggunakan perspektif bahwa semuanya adalah kehendak Allah SWT. Kerelaan menerima dengan ikhlas inilah membawa pada penurunan depresi dan peningkatan imunitas secara signifikan. Perubahan tersebut tidak dapat dipisahkan dari rasa tenang sesudah membaca Al Quran. (Julianto, V. 2015).

\section{Terus Berusaha Berkarya Lebih Kreatif dan Inovatif}

Dahlan Iskan dalam memberikan saran agar segera melakukan perubahan cara berbisnis karena selama pandemi Covid-19 ini pasar berubah. Penuhilah keperluan perubahan itu seperti kebutuhan ibu-ibu untuk belanja sayuran dan kebutuhan sehari-hari barang yang diperlukan saat ini: odol, sikat gigi, sabit, sanitasi, dan sebangsanya. Anda bisa menggantikan Indomaret dan Alfamart. Jadilah pasar keliling karena keengganan ibu-ibu kepasar terkait isoasi diri. Membuka tempat cukur dengan prosedur penanganan Covid-19 diantaanya menggunakan APD, merubah hotel sebagai tenpat nyaman dan aman untuk isolasi mandiri dengan mem berikan jaminan kesterilannya seperti rumah sakit. Anda latih karyawan hotel dengan prosedur baru --menjadi seperti perawat. Belilah APD untuk semua karyawan hotel. Pemilik restoran yang sepi segera berubah membuat makanan untuk bisa diantarkan kerumahrumah dengan pesanan online (Dahlan, suara.com, 2020). Hal ini senada dengan penyampaian Rina (34) pengusaha desain dan dekorasi yang banyak kehilangan order dimasa Covid-19 dan beralih kepada penjualan retail beras yang didistribusikanya langsung kepada konsumen, “ Iya pak.. sekarang harus pintar cari jalan supaya pengahasilan tetap ada buat keluarga. Kebutuhan orang kita petakan lalu kita tawarkan untuk diantar kerumah. Insyallah selalu ada jalan...”. Rina (34).

Perusahaan yang dapat bertahan dalam persaingan bisnis, harus menggunakan strategi yang berorientasi pada nilai-nilai inovatif dan efisien dengan melihat sumber daya dan 
kemampuan perusahaan secara holistik. Ketika perusahaan industri raksasa menggunakan strategi Red Ocean dalam perluasan persaingan pasar, perusahaan industri kopi kecil dan menengah (UMKM) harus mengambil strategi alternatif Blue Ocean menjadi pilihan strategis. Pilihan strategi yang melakukan diferensiasi fokus. Merumuskan penggunaan strategi Blue Ocean dengan membentuk konsep baru sesuai perubahan kebutuhan pelanggan untuk kelangsungan hidup dan ekspansi di luar arena Red Ocean. (Setiawan \& Komara, 2020).

\section{Mencari Sumber Permodalan Murah dan Restrukturisasi Kredit yang Ada}

Menteri Keuangan (Menkeu) Sri Mulyani tengah mempertimbangkan, penerbitan surat utang khusus untuk para pelaku Usaha Mikro Kecil dan Menengah (UMKM). Utamanya bagi pelaku usaha mikro, kecil, dan menengah yang saat ini mengalami kesulitan likuiditas. Pemerintah terus berusaha memberikan stimulus bagi pelaku UMKM agar bisa keluar dari dampak virus corona. Sebab sektor UMKM ini merupakan penyelamat di saat krisis ekonomi pada 1998-1999. (Sindo, 2020). Sejalan dengan hal itu Lukman (40) pengusaha desain interior \& furniture menyampaikan," Covid-19 semua mengurangi kegiatan stay at home.. order berkurang banyak sedangkan biaya operasional harus terus dikeluarkan. Modal kita tergerus beberapa bulan sampai normal kembali. Kalau selesai Covid-19 tidak ada pinjaman ringan bakal banyak pegusaha tidak bisa bangkit..."

Wakil Ketua Umum Asosiasi Pengusaha Indonesia (Apindo) Shinta Kamdani mengatakan bahwa pengusaha meminta insentif pajak diringankan agar para pelaku usaha pun bebannya ringan. Ini juga untuk memperpanjang keberlangsungan usaha, Jika dipaksakan toko tetap buka namun tidak ada konsumen yang berbelanja, perusahaan akan bangkrut. tanpa ada keringanan pajak, bisa-bisa para pelaku usaha akan memecat karyawannya.. Jika tidak cepat dilakukan, dua hingga tiga bulan bisa tutup dan $40 \%$ perusahaan di pusat perbelanjaan akan bertumbangan dan susah bangkit," (Sindo, 2020). Melakukan upaya renegosiasi ketentuan kontrak dan hutang dengan bank atau perusahaan multiinanace. UMKM dan pedagang kecil bisa mengajukan restruksisasi kedit. Menurut Otoritas Jasa Keuangan (OJK) terdapat 110 perusahaan multifinance sudah mengumumkan untuk membuka kesempatan restrukturisasi kredit bagi nasabah. (Sitorus, Kompas.com, 2020). Sejalan dengan itu Rina (34) pengusaha desain dan dekorasi menyampaikan," Kondisi ini jauh diluar perhitungan kami, termasuk kredit yang ada kalau harus terus dibayar maka kami kan kesulitan mempertahankan karyawan. Bank harus mau mengerti keadaan pengusaha kecil. Belum lagi 
modal ikut tergerus untuk memulai usaha lagi nanti kalau sudah normal. “ Rina (34).

Mencari pinjaman bunga rendah masih barang mewah untuk UMKM dan Pedagang kecil. Sebelum pandemi Covid-19 mereka sudah esulitan akses pendanaan ini dan bila menilik alokasi pendanaan pemerintah untuk penanganan covid-19 masih terlalu kecil untuk bisa menjangkau seluruh UMKM dan pedagang kecil yang ada. Kita buat pendekatan perbandingan, dimana dunia meningkatkan respons kemampuan penanganan wabah Covid19 melalui ekspansi fiskal yang luar biasa. Sejumlah negara mengalokasikan besaran anggaran kesehatan lebih dari 2 persen dari produk domestik bruto atau PDB untuk mencegah penyebaran virus korona. Sedangkan anggaran Indonesia untuk penanganan pandemik Covid19 masih relatif kecil, yaitu kurang dari 1 persen PDB. Oleh karena itu, tidak cukup jika Indonesia hanya bergantung pada Anggaran Pendapatan dan Belanja Negara (APBN). Sri Mulyani mengatakan, anggaran yang ada untuk penanganan temporer selama 3-6 bulan. Dengan dana itu, pemerintah akan memastikan ketersediaan alat pelindung diri, memberikan insentif bagi tenaga medis berkisar Rp 5 juta-Rp 15 juta per bulan tergantung profesinya, dan mengganti biaya perawatan pasien Covid-19. Seluruh instrumen fiskal di pusat maupun daerah fokusnya adalah untuk kesehatan. Selanjutnya untuk peningkatan jaring pengaman sosial dan bantuan bagi dunia usaha. (Kompas,2020)

Menghadapi krisis ekonomi akibat pandemi ini, Mills merekomendasikan agar pemilik usaha kecil di AS agarmelakukan upaya :1) Mencari pinjaman dengan biaya rendah. Selain pinjaman bencana, yang hanya berlaku untuk bisnis di negara-negara yang telah menyatakan status darurat, beberapa pemerintah negara bagian menawarkan paket bantuan. Cari swasta yang menawari program serupa seperti Facebook mengatakan akan menawarkan hibah \$ 100 juta untuk usaha kecil perusahaan fintech seperti Kabbage dan Fundbox, yang berspesialisasi dalam pinjaman untuk usaha kecil, juga mempertimbangkan cara untuk mendukung sektor ini. 2) Renegosiasikan ketentuan kontrak dan hutang. Pemilik harus meminta tuan tanah lebih banyak waktu untuk membayar sewa, misalnya. Mereka juga harus meminta bank untuk menunda sementara pembayaran bunga atas hutang yang belum dibayar. (Kost, 2020)

\section{Melalui Komunitas Sosial Membentuk Kekuatan Ekonomi}

Modal sosial masih relevan untuk menggerakkan energi sosial mengatasi berbagai permasalahan yang ada di masyarakat. Implementasi modal sosial dengan membangun gerakan kolektif melawan wabah Covid-19 diantaranya dengan saling mengingatkan untuk 
mematuhi protokol pencegahan penyebaran virus sampai lingkungan terkecil RT/RW, memperkuat imunitas mental masyarakat agar tidak mengalami wabah gangguan kesehatan mental akibat corona, dan jejaring antar kelompok harus diperkuat untuk membangun kekuatan lebih besar misalkan untuk ketahanan ekonomi dengan membuka pasar bersama penjual dan pembeli dari kelompok sendiri. (Badri, newsdetik.com, 2020)

Sejalan dengan hal itu Joni (54) ketua RT 08 Kelurahan Pagesangan Surabaya mengatakan," selain karantina wilayah dengan penutupan akses masuk selain warga pada jam-jam tertentu, kita juga hidupkan pasar warga. Kita persilahkan warga yang memiliki produk barang/jasa untuk ditawarkan kepada warga sendiri dengan tetap memperhatikan sosial distancing. Tempat kita juga menyalurkan bantuan sosial bagi warga yang kurang mampu. Kita pastikan kebutuhan warga tetap terpenuhi selama masa karantina wilayah mandiri. "Joni(54). Apa yang terjadi di wilayah tersebut juga sesuai dengan saran Wills, dimana upayakan agar Konsumen yang peduli dapat membantu dengan membeli Voucher atau kupon pembelian barang dari bisnis lokal mereka, gerakan kecil yang dapat membantu UMKM dan pedagang kecil agar bisa tetap bertahan. serta cara terbaik untuk mendapatkan uang ke bisnis ini. (Kost,2020).

Modal Sosial adalah suatu sumberdaya yang ada pada individu-individu yang berasal dari interaksi kelompok karena adanya kepercayaan, hubungan timbal balik, dan kerjasama .Perluasan modal sosial yang positif, terutama dalam komunitas dengan sumberdaya ekonomi dan politik yang terbatas, secara konsekuen akan menghasilkan peningkatan kinerja ekonomi dan politik dan peningkatan kualitas kehidupan (Carpenter, 2004).

\section{PENUTUP}

Kemampuan bertahan umkm dan pedagang kecil kurang dari 1 bulan. Sementara mereka dituntut untuk tetap menghasilkan sesuatu untuk menutupi kebutuhan rumahatangga dan beberapa kebutuhan operasional dasar bisnisnya seperti biaya sewa tempat, kredit, karyawan dan lain sebagaimana. Untuk itu itu mereka melakukan upaya maksimal dipusatkan pandemi covid -19 diantaranya adalah: Dengan kesadaran penuh secara ikhlas menerima situasi ini sebagai bagian dari ujian hidup yang diberikan Allah SWT. Pemahaman ini mengantarkan pada kekuatan untuk menghadapi segala permasalahan dan cobaan hidup yang menerpa, serta menjadi bahan rujukan ketika membuat solusi atas permasalahanpermasalahan yang menimpanya. Kerelaan menerima dengan ikhlas inilah membawa pada penurunan depresi dan peningkatan imunitas secara signifikan. Tetap bersyukur hingga saat ini diri, keluarga dan lingkungan secara mayoritas masih diberikan kesehatan oleh Allah SWT 
sehingga masih memiliki harapan untuk berkarya di hari esok. Keikhlasan dan sikap bersyukur diharapkan akan mampu memberi kekuatan moral dan memperkuat imunitas tubuh yang sangat dibutuhkan melawan pandemi virus covid-19 ini. Terus berusaha berkarya lebih kreatif dan inovatif membuat produk atau pemasarannya di tengah situasi ketidakpastian. Segera melakukan perubahan cara berbisnis karena selama pandemi Covid-19 ini pasar berubah dimana pelanggan banyak tinggal dirumah. Dengan memaksimalkan produk bersih/higienis, ramah lingkungan, optimal memanfaatkan keunggulan alam indonesia yang subur dan pemasaran dg pola digital marketing sehingga mampu menjangkau pasar yang lebih luas yang tetap bertahan ketika sosial distancing diterapkan. Mencari sumber permodalan murah yang ditawarkan oleh investor, pemerintah atau lembaga keuangan lainya untuk membangkitkan kembali usaha. Melakukan negosiasi dan restrukturisasi kredit yang ada agar bisa memberikan ruang gerak usaha yang cukup untuk bisa kembali bangkit ketika pandemi covid-19 usai dan krisis ekonomi global temngah melanda. Implementasi modal sosial dengan membangun gerakan kolektif melawan wabah Covid-19 diantaranya dengan saling mengingatkan untuk mematuhi protokol pencegahan penyebaran virus sampai lingkungan terkecil RT/RW, memperkuat imunitas mental masyarakat agar tidak mengalami wabah gangguan kesehatan mental akibat corona, dan jejaring antar kelompok harus diperkuat untuk membangun kekuatan lebih besar misalkan untuk ketahanan ekonomi dengan membuka pasar bersama penjual dan pembeli dari kelompok sendiri, serta mengupayakan penerbitan voucher belanja kepada komunitas sehingga dana yang terhimpun bisa menjadi alternatif modal usaha. Cara ini juga sebagai bentuk perwujudan sikap saling tolong menolong.

Dengan mempertimbangkan deskripsi hasil penelitian serta merujuk pada keterbatasan dari penelitian yang dilakukan, maka melalui penelitian ini disarankan sebagai berikut : UMKM dan Pedagang kecil tentu saja tidak akan bisa bertahan sendiri pada krisis global kali ini yang begitu kompleks karena ketidakpastian yang sangat tinggi. Maka diperlukan dukungan semua satakeholder bisnis yaitu pelaku usaha, investor, kreditur, masyarakat dan pemerintah untuk bersama-sama bangkit bersatu bersama melawan pandemi Covid-19 dan efek krisis global yang dibawanya. Penelitian lebih lanjut perlu diketahui kemungkinannya apakah melalui pandemi Covid-19 dan Krisis Global ini memungkinkan perekonomian Indonesia akan bisa dikelola dengan baik menggunakan sistem kemandirian mengingat sumber daya alam dan sumber daya manusia di Indonesia sangat berlimpah. 


\section{DAFTAR PUSTAKA}

Carpenter, J.P, et al. (2004). Social Capital and Trust in South-east Asian Cities. Urban.

CNBN. (2020). Alarm Keras dari Pengusaha: Kami Cuma Kuat Sampai Juni. Bisa diakses di https://www.cnbcindonesia.com/news/20200406213517-4-150158/alarm-keras-daripengusaha-kami-cuma-kuat-sampai-juni.

Dahlan. (2020). Dahlan Iskan Ajak Masyarakat Move On dari Isu Covid-19.bisa diakses disini https://www.suara.com/bisnis/2020/04/08/161042/dahlan-iskan-ajak-masyarakat-moveon-dari-isu-covid-19.

Daymon, C., \& Holloway, I. (2007). Metode-Metode Riset Kualitatif Dalam Public Relations dan Marketing Communications. Bentang Pustaka.

Fernandes, N. (2020). Economic Effects of Coronavirus Outbreak (COVID-19) on The World Economy. Available at SSRN 3557504.

Putri, G.S. (2020). Prediksi Penyebaran Corona di Indonesia Berubah, Berakhir Awal Juni, bisa diakses di https://www.kompas.com/sains/read/2020/03/23/115440523/prediksipenyebaran-corona-di-indonesia-berubah-berakhir-awal-juni.

Hadiz, V. (2017). Politik, Hubungan Bisnis, dan Negara, Fakultas Ilmu Sosial dan Politik $\begin{array}{llll}\text { Universitas } & \text { Indonesia. } & \text { Selasa, } & 24\end{array}$ https://www.youtube.com/watch?v=3EOhIuKfiq4

Haristiana, H. (2005). Pengaruh Kredit Bagi Hasil BTM Surya Mentari Terhadap Peningkatan Pendapatan Pedagang Kecil di Desa Karanganyar Kabupaten Pekalongan, Doctoral dissertation, Universitas Negeri Semarang.

Ihsanuddin. (2020). Fakta Lengkap Kasus Pertama Virus Corona di Indonesia, https://nasional.kompas.com/read/2020/03/03/06314981/fakta-lengkap-kasus-pertamavirus-corona-di-indonesia?page=all.

Julianto, V. (2015). Membaca Al Fatihah reflektif intuitif untuk menurunkan depresi dan meningkatkan imunitas, Jurnal Psikologi, 42 (1): 34-46.

Kusnadi, D.S., and Darma, G.S. (2018). Menakar Implementasi Green Marketing Pada Usaha Kecil Menengah, Jurnal Manajemen \& Bisnis, 15 (1): 1-18.

Komara, BD., Kirono, I, Saepuloh, A. (2019). Manajemen Diri. UMG Press.

Kusuma, P. O., \& Darma, G. S. (2020). Mobile Payment Transaction on MSMEs. International Research Journal of Management, IT \& Social Sciences, 7(3), 104-109. https://doi.org/10.21744/irjmis.v7n3.926

Kost, D. (2020). How Small Businesses Can Survive the Coronavirus Outbreak, bisa diakses di 
https://hbswk.hbs.edu/item/how-small-businesses-can-survive-the-coronavirus-outbreak Khofifah. (2020). Beda Istilah Karantina Wilayah antara Pemprov Jatim dengan Pemkot Surabaya, Kumparan.com, bisa diakses di: https://kumparan.com/kumparannews/bedaistilah-karantina-wilayah-antara-pemprov-jatim-dengan-pemkot-surabaya-1t7yPbAoTPa Khofifah. (2020). Setengah Wilayah Jawa Timur Sudah Masuk Zona Merah Corona (1 April 2020) https://news.detik.com/berita-jawa-timur/d-4960557/setengah-wilayah-jawa-timursudah-masuk-zona-merah-corona.

Komara, B.D. and Kurniawan, A. (2020). Solve the Problem for Student Entrepreneurship, Chapter-04, 2 (1): 1-8.

Komara, B.D., and Prasetya, A. (2019). Konstruksi Sosial pada Pedagang Tradisional dalam Menghadapi Era Kompetisi Perdagangan Bebas, Jurnal Riset Entrepreneurship, 2 (1): 18.

Kompas. (2020). Dana Penanganan Covid-19 di Indonesia Relatif Kecil. Bisa diakses di https://bebas.kompas.id/baca/bebas-akses/2020/03/25/dana-penanganan-covid-19-diindonesia-relatif-kecil/

Kurniawan, A., Sukaris., and Asharudin. (2019). Small and Medium Enterprises (SMEs) Barriers in Running a Business, 1st International Conference on Innovation in Research (ICIIR 2018), Advances in Economics, Business and Management Research, Atlantis Press: 27-31.

Badri, M. (2020). Menggerakkan Modal Sosial Atasi Bencana Corona, bisa diakses di https://news.detik.com/kolom/d-4962462/menggerakkan-modal-sosial-atasi-bencanacorona.

Nainggolan, E.U.P. (2020). Kebijakan Fiskal dan Moneter Mengadapi Dampak Covid-19. Bisa diakses di https://www.djkn.kemenkeu.go.id/kanwil-kalbar/ baca artikel/13017/Kebijakan-Fiskal-dan-Moneter-Mengadapi-Dampak-Covid-19.html

Ozili, P. K., \& Arun, T. (2020). Spillover of COVID-19: impact on the Global Economy. Available at SSRN 3562570.

Prasetya, A., and Komara, B.D. (2019). Perlawanan Pedagang Kaki Lima Terhadap Kebijakan Relokasi Pemerintah Daerah, Jurnal Riset Entrepreneurship, 2 (2): 1-7.

Sitorus, R. (2020). Dampak COVID-19, Ini 48 Daftar Leasing yang Berikan Keringanan Kredit. bisa diakses di https://finansial.bisnis.com/read/20200406/89/1223407/dampak-covid-19ini-48-daftar-leasing-yang-berikan-keringanan-kredit-

Setiawan, H. C. B., \& Komara, B. D. (2020). The Alternative Blue Ocean Strategy: Bagaimana 
Strategi Perusahaan Industri Kopi Santri Dalam Menghadapi Persaingan Bisnis?, Jurnal Riset Entrepreneurship, 3 (1): 26-32.

Sindo. (2020). Terseok-seoknya Dunia Usaha Menghadapi Simalakama Corona. https://ekbis.sindonews.com/read/1578322/39/terseok-seoknya-dunia-usahamenghadapi-simalakama-corona-1585955706

Suci, Y. R. (2017). Perkembangan UMKM (Usaha mikro kecil dan menengah) di Indonesia, Cano Ekonomos, 6 (1): 51-58. 